\title{
ANALISIS PEMBIASAAN PERILAKU BERLITERASI DALAM UPAYA PENINGKATAN KARAKTER OLEH SISWA KELAS VIII-2 SMP ST. IGNASIUS MEDAN
}

\author{
Maria Kartika Nababan \\ Pendidikan Bahasa Indonesia \\ Pascasarjana Universitas Negeri Medan \\ maria.kartika08@gmail.com
}

\begin{abstract}
Abstrak
Literasi memiliki makna dan implikasi dari keterampilan membaca dan menulis dasar ke pemerolehan dan manipulasi pengetahuan melalui teks tertulis, dari analisis metalinguistik unit gramatikal ke struktur teks lisan dan tertulis. Dari beberapa lembaga survey tersebut Indonesia menempati urutan bawah dan itu menunjukkan bahwa kemampuan literasi di Indonesia masih rendah. Riset ini bertujuan untuk mengetahui kemampuan literasi siswa di SMP St. Ignasius dan mengetahui strategi yang tepat untuk meningkatkan kemampuan literasi siswa. Pengumpulan data secara eksklusif dilakukan pada kelas VIII-2 dengan jumlah siswa 30 orang. Riset ini dimulai dari bulan Agustus sampai Oktober 2018. Hasil mini riset ini bahwa perpustakaan mini kelas efisien untuk pembiasaan membaca siswa. Kemudian, dapat dilihat bahwa siswa pada dasarnya memiliki keinginan untuk membaca meskipun ada yang membaca hanya sekilas dan melihat judul terlebih dahulu. Hal tersebut dapat diatasi apabila guru tetap rutin memperhatikan kegiatan membaca siswa sampai akhirnya ia terbiasa dengan kegiatan membaca. Dengan demikian dapat disimpulkan bahwa siswa SMP St.Ignasius Medan masih berada pada tahap pembiasaan membaca.
\end{abstract}

Kata kunci: buku, literasi, siswa, perpustakaan mini, sekolah

\section{A. Pendahuluan}

Istilah "literasi" memiliki makna meluas dari waktu ke waktu. Literasi sekarang tidak hanya diartikan sebagai kemampuan menulis dan membaca tetapi "... has instead come to be considered synonymous with its hoped-for consequences" (Aronoff,1995: 68). Kini, literasi memiliki makna dan implikasi dari keterampilan membaca dan menulis dasar ke pemerolehan dan manipulasi pengetahuan melalui teks tertulis, dari analisis metalinguistik unit gramatikal ke struktur teks lisan dan tertulis, dari dampak sejarah manusia ke konsekuensi filosofis dan sosial pendidikan barat (Goody \& Watt, 1963; Chafe \& Danielewicz, 1987; Olson, 1991; Ong, 1992). Bahkan perubahan evolusi manusia merupakan dampak dari pemikiran literasi (Donald, 1991). 
Beberapa survei literasi yang diikuti Indonesia antara lain PIRLS dan PISA. PIRLS (Progress in International Reading Literacy Study) adalah studi internasional tentang literasi membaca untuk siswa sekolah dasar (kelas IV) yang dikoordinasikan oleh IEA (The International Association for the Evaluation of Educational Achievement, berkedudukan di Amsterdam, Belanda). Dari beberapa lembaga survey tersebut Indonesia menempati urutan bawah dan itu menunjukkan bahwa kemampuan literasi di Indonesia masih rendah. Khusus untuk kompetensi membaca,subskala yang dipakai adalah kemampuan siswa dalam memeroleh informasi (retrieving information), menginterpretasi teks (interpreting text), dan merefleksikan teks (reflecting text).

Deklarasi Praha (2003) menyebutkan bahwa literasi mencakup bagaimana seseorang berkomunikasi dalam masyarakat. Literasi juga bermakna praktik dan hubungan sosial yang terkait dengan pengetahuan dan budaya. Melalui kegitan literasi, karakter siswa diperkuat melalui harmonisasi olah hati, olah rasa, olah pikir, dan olah raga dengan dukungan pelibatan publik dan kerja sama antara sekolah, keluarga, dan masyarakat. Kegiatan gemar membaca adalah kebiasaan menyediakan waktu untuk membaca dan berbagi bacaan yang memberikan kebijakan bagi dirinya atau berbagi informasi. Maka melalui kegiatan literasi, siswa diharapkan mampu mengembangkan kemampuan dan watak serta peradaban bangsa yang bermartabat dalam rangka mencerdasakan kehidupan bangsa serta mengembangkan potensi siswa agar menjadi manusia yang bertakwa pada Tuhan Yang Maha Esa, berakhlak mulia, sehat, berilmu, cakap, kreatif, mandiri, dan menjadi warga negara yang demokratis dab bertanggung jawab.

Kajian mengenai literasi di tingkat SMP tidak dapat dipisahkan dari survei kompetensi literasi, yaitu aspek literasi yang diukur adalah memahami, menggunakan, merefleksikan, dan mencipta dalam bentuk tulisan. Untuk sampai pada tahap mencipta sesuatu, siswa harus memiliki minat baca. Namun, minat baca pada siswa masih dapat dikategorikan rendah, khususnya siswa di SMP St. Ignasius. Serangkaian upaya telah dilakukan oleh sekolah untuk mendukung kegiatan literasi di sekolah, hanya saja belum menunjukkan hasil yang signifikan. Untuk itu, pada mini riset ini akan diidentifikasi perilaku membaca siswa SMP agar guru dapat memahami kebutuhan siswa dalam membaca. Riset ini akan dilakukan di kelas VIII-2 SMP St. Ignasius Medan.

Berdasarkan pemaparan tersebut, maka mini riset ini membuat suatu hipotesis sebagai berikut.

1. Perilaku membaca siswa berpengaruh pada upaya peningkatan karakter berpikir kritis melalui kegiatan literasi siswa.

2. Strategi dibutuhkan untuk meningkatkan literasi di sekolah-sekolah khususnya SMP St. Ignasius.

Riset mini ini bertujuan untuk : 
1. Mengetahui kemampuan literasi siswa di SMP St. Ignasius.

2. Mengetahui strategi yang tepat untuk meningkatkan kemampuan literasi siswa.

\section{B. METODE PENELITIAN}

Dalam riset mini ini akan dilakukan pengumpulan data dengan cara meneliti kegiatan literasi siswa SMP. Adapun data narasumber adalah sebagai berikut.

Kelas $\quad:$ VIII-2

Sekolah $\quad$ : SMP St. Ignasius Medan, Jalan Karya Wisata No. 6 Medan Johor

Riset ini akan menjawab pertanyaan tentang bagaimana perilaku membaca siswa SMP dan apa strategi yang dapat diambil untuk meningkatkan minat baca siswa. Kemudian, membuktikan hipotesis bahwa ada keterkaitan perilaku membaca siswa dengan pemilihan strategi peningkatan kemampuan literasi siswa dan kegiatan literasi sekolah merupakan cara efektif sebagai upaya meningkatkan minat baca siswa. Kegiatan literasi dengan menggunakan perpustakaan mini ini telah dilakukan di beberapa kelas di SMP St.Ignasius, seperti kelas VIII-1, VIII-2, VIII-3, dan IX-2. Namun, pengumpulan data secara eksklusif dilakukan pada kelas VIII-2 dengan jumlah siswa 30 orang dengan membuat daftar nama peminjam buku mulai dari bulan Agustus sampai Oktober 2018. Dari daftar tersebut ditemukan beberapa kebiasaan membaca siswa.

Rangkaian kegiatan yang dilakukan adalah sebagai berikut.

1. Siswa diminta untuk membawa buku yang mereka sukai, kecuali novel dan komik, 1 buku per siswa pada awal bulan Agustus

2. Siswa mengumpulkan buku-buku tersebut dan membuat perpustakaan mini di kelas.

3. Guru memilih 3 orang penanggung jawab perpustakaan mini di kelas.

4. Siswa penanggung jawab perpustakaan mini membuat daftra nama peminjam buku yang akan diisi secara rutin, ketika siswa meminjam buku dari perpustakaan mini.

5. Siswa dan guru membuat kesepakatan dalam menggunakan perpustakaan mini kelas, seperti lamanya waktu peminjaman, konsekuensi bagi yang tidak mengembalikan buku tepat waktu, dsb.

6. Siswa bebas meminjam buku di jam istirahat atau di luar waktu literasi dan jam pelajaran.

7. Guru akan memeriksa daftar buku di kelas secara rutin setiap 2 minggu sekali.

Rangkaian kegiatan tersebut dilakukan dengan rutin setiap harinya, khususnya hari Kamis, Jumat, dan Sabtu karena sekolah menjadikan hari tersebut sebagai hari literasi.

\section{HASIL DAN PEMBAHASAN}


Mini riset ini berangkat dari permasalahan literasi di Indonesia yang dilihat dalam hasil survey beberapa lembaga survey yang diikuti oleh Indonesia. Menurut hasil survey tersebut ternyata Indonesia menempati posisi yang dapat dikatakan buruk karena ada pada peringkat bawah. Kementerian Pendidikan dan Kebudayaan telah berupaya dengan membuat kebijakan terkait dengan budaya membaca. Kebijakan tersebut diantaranya adalah Peraturan Menteri Pendidikan dan Kebudayaan Nomor 23 Tahun 2015 tentang Penumbuhan Budi Pekerti, salah satunya, mengenai kegiatan membaca buku nonpelajaran selama lima belas menit sebelum waktu belajar dimulai.

Kegiatan tersebut adalah upaya menumbuhkan kecintaan membaca kepada peserta didik dan pengalaman belajar yang menyenangkan sekaligus merangsang imajinasi. Sebagai turunan peraturan menteri tersebut telah di sosialisasikan pula pada seluruh sekolah di Indonesia tentang Gerakan Literasi Sekolah meliputi 3 tahapan yakni: 1) penumbuhan minat baca, 2) meningkatkan kemampuan literasi buku pengayaan dan 3) meningkatkan kemampuan literasi buku pelajaran (Kemdikbud, 2016).

Setelah melalukan rangkaian kegiatan di atas, pada bulan Oktober, data yang diperoleh diperoleh dari penelitian tersebut, yakni:

\section{Pembiasaan Membaca Siswa}

Membawa buku

\begin{tabular}{|c|l|}
\hline \multicolumn{1}{|c|}{ Bulan } & \multicolumn{1}{|c|}{ Jumlah Buku yang Dibawa Siswa } \\
\hline Agustus & \\
\hline Minggu 1 & 24 buku \\
\hline Minggu 3 & 33 buku \\
\hline September & \\
\hline Minggu 1 & 28 buku \\
\hline Minggu 2 & 30 buku \\
\hline Oktober & \\
\hline Minggu 1 & 30 buku \\
\hline
\end{tabular}

Tabel 1. Jumlah buku yang di bawa siswa

Berdasarkan data di atas terlihat adanya perubahan jumlah buku yang di bawa oleh siswa. Adapun penyebab adanya perubahan jumlah buku ini, antara lain:

\section{Agustus}


- Minggu ke-1: Siswa tidak memiliki buku, selain komik dan novel ataupun buku-buku milik orang tua di rumahnya. Kemudian guru kembali memberi motivasi oleh siswa terkait kegiatan literasi.

- Minggu ke-2 : Pada minggu ke-2, seluruh siswa telah memiliki buku masing-masing dan ada siswa yang membawa buku lebih dari satu. Hal itu yang menyebabkan jumlah buku pada minggu ke-2 Oktober mencapai jumlah 33 buku. Hal ini menunjukkan perkembangan yang baik.

\section{September}

- Minggu ke-1 : Jumlah buku di perpustakaan mini kelas VIII-2 mengalami penurunan. Hal ini disebabkan adanya siswa yang membaca buku dan membawanya pulang kemudian lupa membawanya kembali ke sekolah.

- Minggu ke-2 : Jumlah buku bertambah sejumlah siswa di kelas karena siswa telah membawa kembali buku bacaannya ke sekolah.

\section{Oktober}

- Minggu ke-1 : Buku masih pada jumlah yang sama dengan minggu ke-2 November, yakni sejumlah 30 buku.

\section{Perilaku Membaca Siswa}

\begin{tabular}{|l|l|l|l|}
\hline Perilaku membaca siswa & \multicolumn{1}{|c|}{ Agustus } & \multicolumn{1}{|c|}{ September } & \multicolumn{1}{|c|}{ Oktober } \\
\hline Membaca serius & $100 \%$ & $66,6 \%$ & $33 \%$ \\
\hline $\begin{array}{l}\text { Membaca karena tugas/ } \\
\text { hari literasi/ diwajibkan }\end{array}$ & $100 \%$ & $90 \%$ & $90 \%$ \\
\hline Membaca dan mencatat & $100 \%$ & $66,6 \%$ & $16,6 \%$ \\
\hline Menanya makna kata & $16,6 \%$ & $16,6 \%$ & $6,6 \%$ \\
\hline Membaca sekilas & $0 \%$ & $0 \%$ & $33 \%$ \\
\hline Membaca melihat judul & $0 \%$ & $33 \%$ & $33 \%$ \\
\hline
\end{tabular}

Tabel 2. Perilaku membaca siswa 


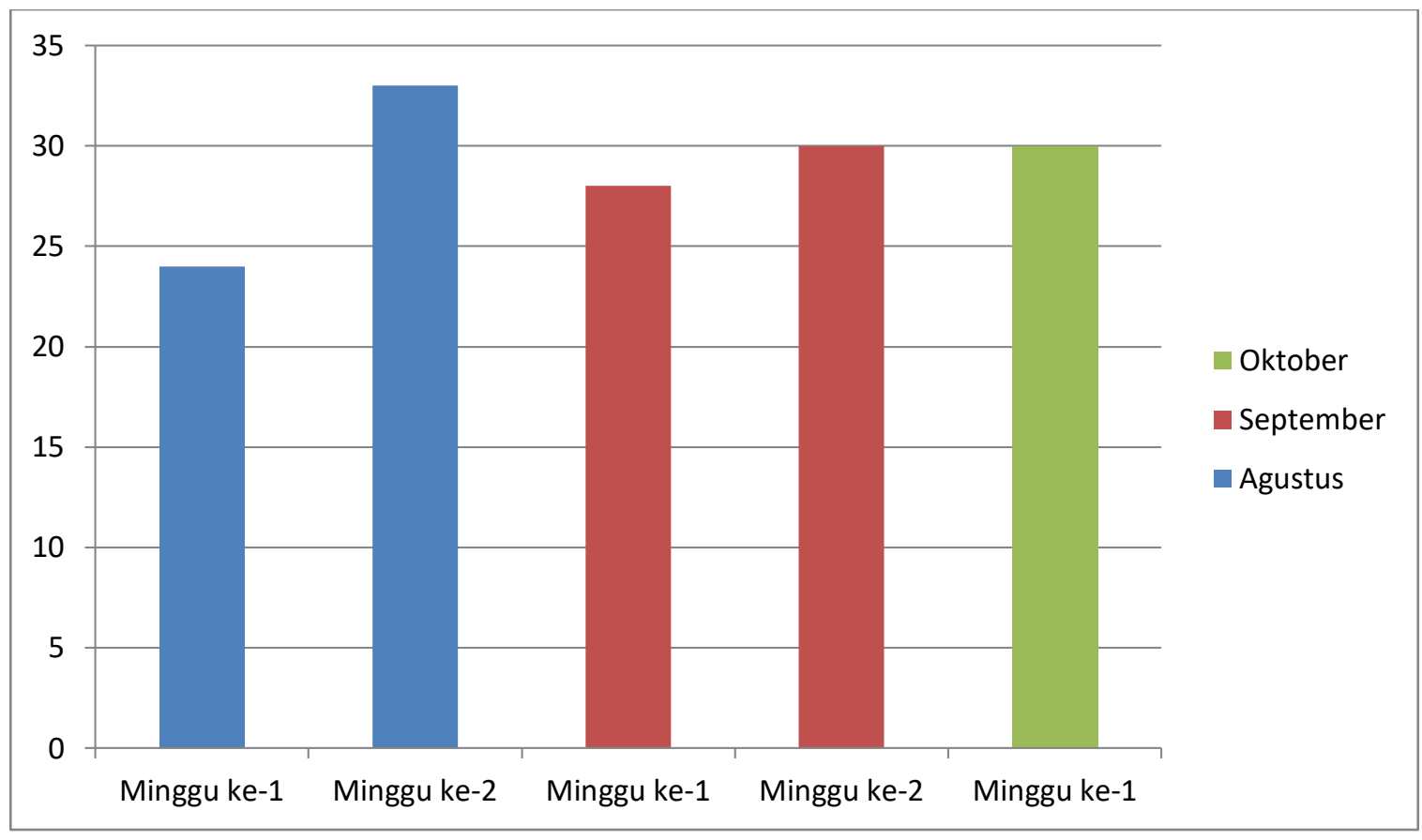

\section{Grafik 1. Siswa yang membawa buku}

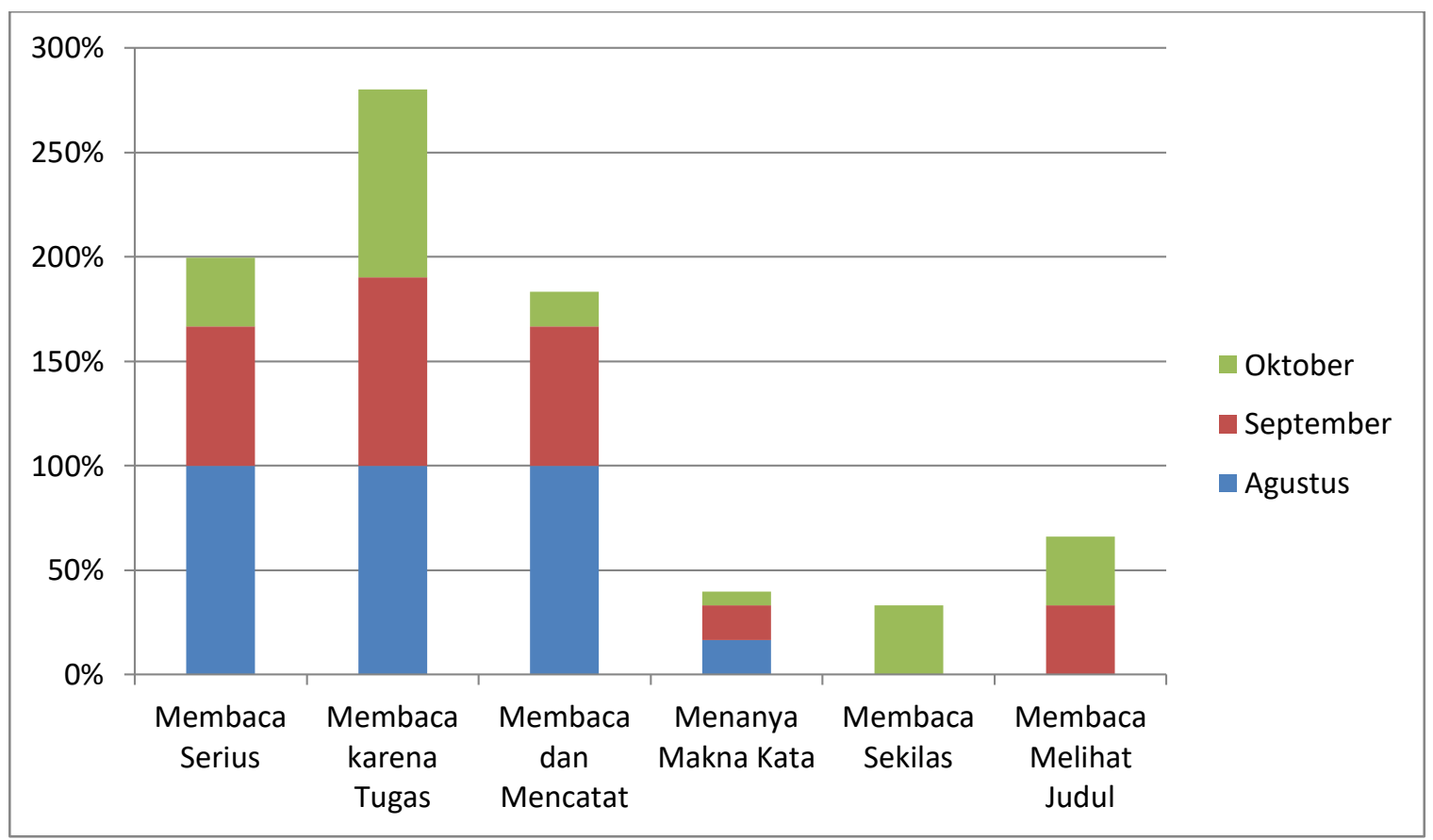

\section{Grafik 2. Perilaku membaca siswa (dalam \%)}

Berdasarkan data di atas diperoleh hasil bahwa upaya pembiasaan kegiatan membaca siswa dilihat dari antusias siswa membawa buku ke sekolah untuk dijadikan buku di perpustakaan mini kelas menunjukkan peningkatan. Hal itu dapat dilihat dari jumlah buku yang meningkat dari minggu ke-1 bulan Agustus (awal kegiatan pembiasaan) dan meningkat pada minggu ke-2. Namun, kembali mengalami penurunan pada minggu ke 1 bulan September. Hal ini dikarenakan siswa merasa tertarik 
dengan buku bacaan sehingga siswa membawa buku dari perpustakaan mini ke rumah dan dibaca di rumah. Selanjutnya, jumlah buku pada minggu berikutnya hingga akhir riset ini menunjukkan jumlah yang tetap, yakni 30 buku (sebanyak jumlah siswa). Data pembiasaan kegiatan membaca siswa dengan membawa buku kesukaan untuk dijadikan buku di perpustakaan mini kelas ternyata memberikan dampak yang baik bagi perkembangan minat baca siswa.

Selanjutnya pada grafik 2, dapat dilihat bagaimana perilaku membaca siswa. Meskipun pada grafik 1 dijelaskan bahwa siswa mulai terbiasa dengan buku dan mulai tertarik dengan buku. Namun pada grafik 2 persentase jumlah siswa yang membaca serius setiap bulannya mengalami penurunan. Begitu pula perilaku membaca dan mencatat, menanya makna kata. Kemudian pada perilaku membaca siswa, yaitu membaca sekilas dan membaca melihat judul meningkat per bulannya. Siswa terlihat begitu antusias membaca hanya di saat guru memberikan kegiatan wajib baca untuk mengerjakan tugas ataupun saat hari literasi. Namun, pada bulan September dan Oktober, jumlah siswa yang membaca karena tugas/ hari literasi menurun karena adanya siswa yang tidak hadir. Untuk melihat siswa membaca dengan serius dan mencatat bacaannya hingga menemukan katakata sulit akan jarang ditemukan di luar hari literasi ataupun proses pengerjaan tugas.

Berdasarkan data-data di atas, dapat dilihat keefisienan perpustakaan mini kelas terhadap pembiasaan membaca siswa. Kemudian, dapat dilihat bahwa siswa pada dasarnya memiliki keinginan untuk membaca meskipun ada yang membaca hanya sekilas dan melihat judul terlebih dahulu. Hal tersebut dapat diatasi apabila guru tetap rutin memperhatikan kegiatan membaca siswa sampai akhirnya ia terbiasa dengan kegiatan membaca. Ini dikarenakan jumlah siswa yang membaca buku ketika diwajibkan oleh guru sangat tinggi jumlahnya. Dengan demikian, pembiasaan membaca siswa yang dilakukan di kelas VIII-2 SMP St. Ignasius Medan berjalan dengan baik, khususnya pada hari-hari literasi yang ditentukan oleh sekolah. Untuk itu, guru hendaknya mencari strategi lain untuk membantu siswa terbiasa dengan kegiatan membaca dan mengubah perilaku membacanya.

\section{SIMPULAN}

Persoalan rendahnya budaya membaca dan rendahnya kemampuan literasi siswa tidak perlu diratapi apalagi sibuk mencari pihak yang bersalah. Jalan yang terbaik adalah masing-masing komponen bangsa Indonesia menjalankan perannya masing-masing dan memberikan solusi nyata untuk mengatasi akar permasalahan tersebut. Menentukan strategi yang tepat adalah langkah utama yang harus dikembangan oleh guru dan pihak sekolah.

Pembiasaan membaca siswa yang dilakukan di kelas VIII-2 SMP St. Ignasius Medan berjalan dengan baik, khususnya pada hari-hari literasi yang ditentukan oleh sekolah. Sehingga sekolah perlu menindaklanjuti program literasi di sekolah dengan mencari strategi-strategi lainnya. Penentuan 
strategi itu akan lebih mudah ketika pihak sekolah sudah mengetahui perilaku membaca siswa. Dengan taraf literasi siswa yang masih sampai pada taraf pembiasaan literasi, belumlah menunjukkan taraf yang memungkinkan untuk siswa mengembangkan karakter seperti yang diharapkan pada penjelasan di atas. Untuk itu sunggu dibutuhkan strategi lain dalam peningkatan taraf literasi siswa.

\section{DAFTAR PUSTAKA}

Aronof, M. 1994. Spelling and culture.Dalam W.C. Watt (Ed). Writing system and cognition, Dordrecht: Kluwer.

Benson, V. 2002. Shifting paradign and pedagogy with nonfiction: A call to arms for survival in the 21st century. The New England Reading Association Journal, 38, 1-6. Diunduh pada 15 Maret 2013. http://www.proquest/umi/pqd.web

Chafe, W. 1994. Discourse, consciusness, and time. Chicago: The University of Chicago Press. Cladwell, J. S. (2008). Comprehension assessment: A classroom guide. New York: Th

Donald, M. 1991. Origins of the modern mind: three stages in the evolution of culture and cognition. Cambridge MA: Harvard University Press.

Goody, J. \& Watt, I. 1963. The consequences of literacy. Contemporary Studies in Society and History

5, Diunduh pada 15 Maret 2013 http://www.proquest/ umi/pqd.web

Kemdikbud, 2016. Manual Pendukung Pelaksanaan Gerakan Literasi Sekolah untuk Jenjang SMP. Jakarta: Dirjen Dikdasmen.

Ong, W.J. 1992. Writing is a technology that restructures thought. Dalam

P.Downing, S.D. Lima \& M. Noonan (Eds). The Linguistics of literacy. Amsterdam:

John Benjamins.

UNESCO. (2007). Education for all by 2015: Will we make it? EFA global monitoring report 2008. UK: Oxford University Press. 